\title{
MEFV gen mutasyonlarının tüberküloza direnç ile olası ilişkisi
}

\section{A possible association of MEFV gene mutations with resistance to tuberculosis}

\author{
Malik Ejder Yıldırım*, Dilara Yıldırım, Sulhattin Arslan, Hande Küçük Kurtulgan
}

Tıbbi Genetik Anabilim Dalı (Dr. M. E. Yıldırım, Yrd. Doç. Dr. H. K. Kurtulgan), Göğüs Hastalıkları Anabilim Dalı (Doç. Dr. S. Arslan), Cumhuriyet Üniversitesi Tıp Fakültesi, TR-58140 Sivas, Mikrobiyoloji Laboratuvarı (Dr. D. Yıldırım), Sivas Numune Hastanesi, TR-58100 Sivas

\begin{abstract}
Özet
Amaç. Mycobacterium tuberculosis enfeksiyonu dünya üzerinde ciddi bir halk sağlığı sorunudur. T-helper 1 hücreleri tüberküloz patogenezinde önemli bir rol oynamaktadır. Ailesel Akdeniz Ateşi (FMF) hastaları ve taşıyıcılarında T-helper 1'in artmış aktivitesi söz konusudur. Bu çalışmayı, bağışıklık temelinde, MEFV gen mutasyonlarıyla tüberküloza karşı direnç arasında olası ilişkiyi değerlendirmek üzere yaptık. Yöntem. Bu çalışma 2007-2009 yılları arasında Cumhuriyet Üniversitesi Tıp Fakültesi Gögüs Hastalıkları Anabilim Dalı'na başvuran ve fizik muayene, mikrobiyolojik ve radyolojik tetkiklerle tüberküloz tanısı alan 51 hasta ( 23 kadın, 28 erkek) ve 57 kişilik kontrol grubuyla (26 kadın, 31 erkek) gerçekleştirilmiştir. Her iki grupta revers hibridizasyon FMF Strip Assay (ViennaLab Labordiagnostika, Vienna, Austria) tekniği kullanılarak 12 yaygın MEFV gen mutasyonu araştırılmıştır. Bulgular. MEFV mutasyonlarının dağılımı açısından hasta ve kontrol grupları arasında önemli bir fark saptanmamıştır ( $\mathrm{p}>0,05)$. Hasta grubunda $22 \mathrm{MEFV}$ gen mutasyonu (\%43,1) vard1. Homozigot mutasyon tespit edilmedi. Hasta grubundaki mutasyonların tamamı heterozigottu. Kontrol grubunda da homozigot mutasyona rastlanmazken, toplam $29(\% 50,8)$ heterozigot mutasyona rastlandı. Sonuç. Elde edilen veriler tüberküloz hastalarında MEFV geni mutasyon sıklığının sağlıklı populasyona oranla önemli bir farklılık göstermediğini düşündürmektedir. FMF mutasyonları tüberküloza yakalanmakta değil ama hastalığın seyrinde etkili olabilir.
\end{abstract}

Anahtar sözcükler: FMF, tüberküloz, MEFV geni, mutasyon

\begin{abstract}
Aim. Mycobacterium tuberculosis infection is a critical public health problem all over the world. T-helper 1 cells play an important role in the pathogenesis of tuberculosis. There is an increased activity of T-helper 1 in Familial Mediterranean Fever (FMF) patients and carriers. Based on immunity, we undertaken this study to evaluate a possible association of MEFV gene mutations with resistance to tuberculosis. Method. This study was performed with 51 patients (23 females, 28 males) applied to Cumhuriyet University Medical Faculty Chest Diseases Department between 2007 and 2009 and diagnosed with tuberculosis by physical examination, microbiological and radiologic analysis and 57 controls (26 females, 31 males). In these groups, 12 common MEFV gene mutations were researched using revers hybridisation FMF Strip Assay (ViennaLab Labordiagnostika, Vienna, Austria) technique. Results. A significant difference was not detected between patient and control groups in terms of distribution of MEFV mutations ( $>>0.05$ ). There were $22 \mathrm{MEFV}$ gene mutations $(43.1 \%)$ in patient group. Homozygous mutation was not detected in this group. All mutations in patient group were heterozygous. There was also no homozygous mutation in control group and total 29 (50.8\%) heterozygous mutations were detected. Conclusion. Our results suggested that the mutation frequency of MEFV gene in tuberculosis patients was not significantly different from healthy population. FMF mutations may effect the survive of tuberculosis but not sicken.
\end{abstract}

Keywords: FMF, tuberculosis, MEFV gene, mutation

Geliş tarihi/Received: 16 Şubat 2014; Kabul tarihi/Accepted: 15 Ağustos 2014

\section{*İletişim adresi:}

Dr. Malik Ejder Yıldırım, Tıbbi Genetik Anabilim Dalı, Cumhuriyet Üniversitesi Tıp Fakültesi, TR-58140 Sivas. E-posta: mey2002@gmail.com 


\section{Giriş}

Mycobacterium tuberculosis enfeksiyonu dünya üzerinde ciddi bir halk sağlığ sorunu olması ve tedavisine karşı direnç gelişmesi, hastalığın patogenetik mekanizmaları üzerine olan araştırmaların yoğunlaşmasına neden olmuştur $[1,2]$. Tüberküloz immünolojisinde başlıca protektif Th1 sitokinlerden sorumlu CD4 T hücrelerinin kazanılmış immün cevaptaki rolü bilinmektedir. Th1 tip sitokinler patojenik bakterilerin çoğalmasını inhibe eden diğer fagositik ve inflamatuvar hücreleri aktive etmektedir [3].

Ailesel Akdeniz Ateşi (FMF) serözal inflamasyon, rekürren ateş atakları, karın ve eklem ağrıları ile karakterize otozomal resesif 'otoinflamatuvar hastalıklar' olarak isimlendirilen bir grup hastalığın içinde yer almaktadır $[4,5]$. FMF'e neden olan gen MEFV geni (Mediterranean Fever Gene) 16 numaralı kromozomda lokalize olup (16p13,3) 10 ekzona sahiptir ve 781 aminoasitlik pirin adı verilen bir proteini kodlar. Pirin, apopitotik ve inflamatuvar sinyal yolunda fonksiyonu olduğu düşünülen bir proteindir [6-8]. MEFV geninin ürünü olan pirin proteini interlökin $1 \beta$ üretimini inhibe eder. Böylece, MEFV genindeki mutasyonlar Th1 polarizasyonu ve interferon- $\gamma$ 'nın artışı ile seyreden proinflamatuar bir sürece neden olur. $\mathrm{Bu}$ durumun tüberküloz gibi intrasellüler patojenlere karşı bir koruyuculuk sağlaması beklenebilir [9]. Bu çalışmayı, FMF olgularının yoğun olduğu Sivas bölgesinde, MEFV gen mutasyonlarının tüberküloz olguları ve sağlıklı populasyonda sıklığını araştırmak ve tüberküloz hastalığı için MEFV gen mutasyonlarının koruyuculuğunu değerlendirmek amacıyla yaptık.

\section{Gereç ve yöntem}

Çalışmamızda Cumhuriyet Üniversitesi Göğüs Hastalıkları Anabilim Dalı’na 2007-2009 yılları arasında başvuran, yeni tüberküloz teşhisi konmuş 51 hasta (23 kadın, 28 erkek) seçildi. Hasta grubunun oluşturulmasında, hastalardan ayrı zamanlarda 3 ayrı balgam veya bronkoskopi yoluyla bronşial yıkama örneğinden elde edilen kültürlerden (BD, MGIT) en az birinin Mycobacterium tuberculosis kompleksi (MTC) açısından pozitif olması; Antitüberküloz tedaviye radyolojik ve klinik belirgin iyileştirici yanıtlar alınması kriter olarak seçildi. Hastaların immün yetmezliğe yol açan bir hastalık ve ilaç kullanım öyküsüne sahip olmamalarına dikkat edildi. Kontrol grubu gönüllülük esasına dayalı olarak çalışmamıza katılmak isteyen, herhangi bir sistemik hastalığı ve tüberküloz öyküsü olmayan 57 kişiden (26 kadın, 31 erkek) oluşturuldu. Bu kişilerin balgam kültürlerinin ve radyolojik bulgularının tüberküloz açısından negatif olmasına dikkat edildi.

DNA izolasyonu QIAamp DNA mini (Qiagen GmbH, Hilden, Germany) kitleriyle yapıld1. Reverse-hybridization, FMF Strip Assay (ViennaLab Labordiagnostika, Vienna, Austria) tekniği kullanılarak çalışma grupları 12 yaygın MEFV gen mutasyonu (E148Q ekzon 2, P369S ekzon 3, F479L ekzon 5, ve M680I (G/C), M680I (G/A), I692del, M694V, M694I, K695R, V726A, A744S, R761H ekzon 10) açısından tarandı. Bunun için FMF Strip Assay (Vienna Lab Labordiagnostika, Vienna, Austria) kiti kullanıldı. Tüm işlemler üretici firmanın önerileri doğrultusunda yapıldı. MEFV genin amplifikasyonu multiplex polimeraz zincir reaksiyonu (PCR) metoduyla sağlandı. Başarılı amplifikasyon elde edilen PCR ürünlerinin revers hibridizasyon analizi için Reverse-Hybridization (ProfiBlot T48, Tecan, Austria) cihazı kullanıldı. Verilerin analizinde SPSS 15,0 paket programı kullanıldı. Non-parametrik değerlendirme için bağımsız ki-kare testi uygulandı.

\section{Bulgular}

Çalışmamızda alelik bazda toplam mutasyon sayısı ve hasta ve kontrol grubunun genotipleri tespit edildi. (Tablo 1, 2). Her bir mutasyonun tüberküloz hastaları ve kontrol grubundaki sıklığı değerlendirilip istatistiksel analizi yapıldı (Tablo 3). Grupların yaş ve cinsiyet dağılımları benzerdi (Tablo 4).

Hasta grubunda, bir hastada çift mutasyon olmak üzere toplam $22(\% 43,1)$ heterozigot MEFV gen mutasyonuna rastlanırken, homozigot MEFV gen mutasyonuna rastlanmadi. Beş hastada M694V/Wild type, 6 hastada E148Q/Wild type, 3 hastada P369S/Wild type, 
2 hastada M680I (G/C)/Wild type, 1 hastada V726A/Wild type, 3 hastada A744S/Wild type, 1 hastada E148Q/A744S saptand1. Hasta grubunda toplam 21 hastada mutasyon tespit edilirken 30 kişide mutasyon görülmedi (Tablo 2).

Kontrol grubunda da homozigot mutasyona rastlanmazken, dört hastada çift mutasyon olmak üzere toplam $29(\% 50,8)$ heterozigot mutasyon tespit edildi. 4 kişide M694V/Wild type, 8 kişide E148Q/Wild type, 1 kişide P369S/Wild type, 3 kişide M680I (G/C)/Wild type, 3 kişide V726A/Wild type, 2 kişide A744S/Wild type, 1 kişide E148Q/A744S, 1 kişide M680I (G/C)/M694V, 2 kişide M680I (G/C)/E148Q saptand.. Kontrol grubunda toplam 25 bireyde mutasyon görülürken 32 kişide ise mutasyona rastlanmadı (Tablo 2).

Tablo 1. Tüberküloz hastaları ve kontrol grubunda mutasyon oranları.

\begin{tabular}{lll}
\hline Grup & Heterozigot mutasyon & Homozigot mutasyon \\
\hline Hasta & $22(\% 43,1)$ & $0(\% 0)$ \\
Kontrol & $29(\% 50,8)$ & $0(\% 0)$ \\
\hline
\end{tabular}

Tablo 2. Tüberküloz hastaları ve kontrol grubunda MEFV gen mutasyonuna sahip bireylerin genotipi.

\begin{tabular}{lll}
\hline Genotip & Hasta n (\%) & Kontrol n (\%) \\
\hline M694V/Wild type & $5(\% 9,8)$ & $4(\% 7)$ \\
E148Q/Wild type & $6(\% 11,76)$ & $8(\% 14)$ \\
P369S/Wild type & $3(\% 5,8)$ & $1(\% 1,75)$ \\
M680I (G/C)/Wild type & $2(\% 3,9)$ & $3(\% 5,2)$ \\
V726A/Wild type & $1(\% 2)$ & $3(\% 5,2)$ \\
A744S/Wild type & $3(\% 5,8)$ & $2(\% 3,5)$ \\
M680I (G/C)/E148Q & $0(\% 0)$ & $2(\% 3,5)$ \\
E148Q/A744S & $1(\% 2)$ & $1(\% 1,75)$ \\
M680I (G/C)/M694V & $0(\% 0)$ & $1(\% 1,75)$ \\
Wild type/Wild type & $30(\% 58,8)$ & $32(\% 56)$ \\
\hline Toplam & $\mathbf{5 1}$ & $\mathbf{5 7}$ \\
\hline
\end{tabular}

Tablo 3. Tüberküloz hastaları ve kontrol grubunda MEFV gen mutasyonlarının sıklığı.

\begin{tabular}{llll}
\hline Mutasyonlar & Hasta & Kontrol & p değeri \\
\hline M694V & 5 & 5 & $\mathrm{p}=0,625$ \\
E148Q & 7 & 11 & $\mathrm{p}=0,651$ \\
P369S & 3 & 1 & $\mathrm{p}=0,303$ \\
M680I (G/C) & 2 & 6 & $\mathrm{p}=0,440$ \\
V726A & 1 & 3 & $\mathrm{p}=0,625$ \\
A744S & 4 & 3 & $\mathrm{p}=0,447$ \\
Toplam & 22 & 29 & \\
\hline \multicolumn{2}{l}{ p>0,05 (önemsiz) } & & \\
\hline
\end{tabular}

Mutasyon say1s1 kontrol grubunda daha fazla (22/29) olmakla birlikte hasta ve kontrol grupları arasında MEFV gen mutasyonlarının dağılımı açısından istatistiksel olarak anlamlı bir fark bulunmadı. Çalışmamızda elde edilen veriler SPSS programına yüklenerek verilerin değerlendirilmesinde Ki-kare testi kullanılmış ve yanılma düzeyi 0,05 olarak alınmıştır.

Tablo 4. Tüberküloz hastaları ve kontrol grubunun özellikleri.

\begin{tabular}{llll}
\hline Grup & Yaş (ort) & Erkek & Kadın \\
\hline Hasta & $32,3+8,15$ & $28(\% 54,9)$ & $23(\% 45,1)$ \\
Kontrol & $29,8+7,28$ & $31(\% 54,4)$ & $26(\% 45,6)$ \\
\hline
\end{tabular}




\section{Tartışma}

Ailesel Akdeniz Ateşi hastalığından sorumlu MEFV genindeki herhangi bir mutasyon, anormal pirin proteininin sentezine neden olmakta, inflamasyonun etkin olarak baskılanması mümkün olamamaktadır [4, 9]. İnflamasyonun hangi yolla baskılandığı üzerine yapılan çalışmalar sonucunda, pirinin apopitozisi uyardığına dair veriler elde edilmiştir [10]. FMF'deki inflamasyon Th1 polarizasyonu gösterir. Defektif pirin Th1 bağlantılı inflamasyonu inhibe edemediği için FMF hastalarında IFN konsantrasyonlarının daha yüksek seyrettiği öne sürülmektedir [11]. İnterlökin 12 (IL-12) ve 10 (IL-10) sirasiyla Th1 ve Th2 tipi immün yanitta temel rol oynarlar. IL-12 ve IL-18 FMF'te görülen Th1 polarizasyonunun oluşumuna katkıda bulunurlar ve patogenezinde görev alırlar. İnaktif hastalıkta dahi IL-12 ve IL-18 in artmış düzeylerinin tespit edilmesi bu unsurların atakların olmadığ 1 hastalık dönemlerinde Th1 aktivasyonu ve subklinik inflamasyona katıldıklarını düşündürmektedir [12]. FMF hastalığındaki inflamasyon Th1 polarizasyonu gösterir. FMF'deki mutasyonların selektif bir biyolojik avantaj oluşturması konusu açıklığa kavuşturulmamış olmakla birlikte başta tüberküloz basili gibi intrasellüler bakteriler olmak üzere bazı patojenlere karşı daha iyi bir savunma düzeneği kurulabildiği hususunda değişik düşünceler ileri sürülmektedir [13].

Pirin proteini IL $1 \beta$ üretimini inhibe etmektedir. MEFV geninde olası mutasyonlar IL $1 \beta$ aktivitesinin artması ve Th1 polarizasyonuna neden olur. Bu durumun tüberküloz gibi intrasellüler patojenlere karşı bir koruyuculuk sağlaması beklenebilir [14, 15]. Tüberküloz hastaları için yaptığımız FMF mutasyon taraması, tüberküloz hastalarındaki mutasyon sıklığı ile Sivas bölgesindeki normal populasyondaki mutasyon sıklığı arasında anlamlı bir farklılık ortaya koymamaktadır. Bu nedenle tüberküloz hastalığına yakalanma ve basilin organizmada yerleşimine karşı FMF mutasyonlarının koruyuculuk sağladığı söylenemese de bu mutasyonların hastalığın seyrine dönük etkileri olabileceği unutulmamalıdır. Tüberküloz veya benzeri intrasellüler patojenlerle oluşan bir hastalığın varlığında vücudun kendi savunma mekanizmaları devreye girmektedir [16]. Bu tür hastalıklar her bireyde farklı seyir göstermektedir. MEFV gen mutasyonlarının insan bağışıklık sisteminde oluşturduğu değişiklikler konusunda kayda değer oranda bilgi mevcuttur. Sonuç olarak, FMF hastaları ve taşıyıcılarında (heterozigot mutasyon) Th1 aşırı salınımı olmakta, Th1 ise IL2, INF ve TNF gibi proinflamatuar sitokinler üretmekte ve hücresel immünite artmaktadır [17]. MEFV geni INF aracilı inflamasyonda rol oynamakta olup MEFV fonksiyonları Th1 için negatif feedback sağlamaktadır [18]. Öte yanda, her iki hastalığın da AA tipi amiloid birikimine yol açması ilginçtir [19]. Çalışma süresince ikisi tüberküloz komplikasyonları olmak üzere kaybedilen 5 hastada FMF mutasyonu saptanmamıştı. Çalışmamız FMF mutasyonlarının tüberküloz hastalığının oluşumuna karşı istatistiksel olarak anlamlı bir etkisi olabileceğini düşündürmemektedir. Ancak bu mutasyonların sağladığı immün değişikliklerin hastalığın seyrine etkili olması muhtemeldir. MEFV gen mutasyonlarının tüberküloz hastalığının seyrine dönük olası etkilerini araştırmak için mutasyon tespiti yapılan tüberküloz hastalarında tüberküloz hastalığının klinik sürecinin değerlendirildiği ayrıntılı çalışmalara ihtiyaç vardır.

\section{Kaynaklar}

1. Jasmer RM, Seaman CB, Gonzalez LC, Kawamura LM, Osmond DH, Daley CL. Tuberculosis treatment outcomes: Directly observed therapy compared with selfadministered therapy. Respir Crit Care Med 2004; 170: 561-6.

2. JoAnne L. Chan F, Chan J. Immunology of tuberculosis Annual Review of Immunology 2001; 19: 93-129.

3. Romagnani, S. The Th1/Th2 paradigm. Immunol. Today 1997; 18: 263-6.

4. Shinkai K, Kilcline C, Connolly MK, Frieden IJ. The pyrin family of fever genes: Unmasking genetic determinants of autoinflammatory disease. Arch Dermatol 2005; 141: 242-7.

5. Kastner DL. FMF: The genetics of inflammation. Hosp Prac 1998; 33: 131-46. 
6. Samuels J, Ozen S. Familial Mediterranean fever and the other autoinflammatory syndromes: Evaluation of the patient with recurrent fever. Curr Opin Rheumatol 2006; 18: 108-17.

7. Stehlik C. The Pyrin domain in signal transduction. Curr Protein. Pept Sci 2007; 8: 293-310.

8. Keles M, Eyerci N, Uyanik A, Aydinli B, Sahin GZ, Cetinkaya R, Pirim I, Polat KY. The frequency of Familial Mediterranean Fever related amyloidosis in renal waiting list for transplantation. The Eurasian Journal of Medicine 2010; 42: 1920.

9. John J. Goats R. Are the pyrin mutations responsible for Familial Mediterranean Fever protective against Brucellosis. Medical Hypotheses 2007; 68: 3, 499-501.

10. Onen F. Familial Mediterranean fever. Rheumatol Int 2006; 26: 489-96.

11. Aypar E, Ozen S, Okur H, Kutluk T, Besbas N, Bakkaloglu A. Th1 polarization in familial Mediterranean fever. J Rheumatol 2003; 9: 2011-3.

12. Simsek I, Pay S, Pekel A, Dinc A, Musabak U, Erdem H, Sengul A. Serum proinflammatory cytokines directing $\mathrm{T}$ helper 1 polarization in patients with familial Mediterranean fever. Rheumatol Int 2007; 9: 807-11.

13. Cattan D. MEFV Mutation Carriers and Diseases Other than Familial Mediterranean Fever: Proved and Non-Proved Associations; Putative Biological Advantage Current Drug Targets-Inflammation \& Allergy 2005; 4: 1.

14. Ross J. Goats, germs, and fever: Are the pyrin mutations responsible for familial Mediterranean fever protective against Brucellosis? Med Hypotheses 2007; 3: 499-501.

15. Ozen S, Balci B, Ozkara S, Ozcan A, Yilmaz E, Besbas N, Ozguc M, Kastner DL, Bakkaloglu A. Is there a heterozygote advantage for familial Mediterranean fever carriers against tuberculosis infections: Speculations remain. Clin Exp Rheumatol 2002; 20: 57-8.

16. van Crevel R, Ottenhoff T, van der Meer J. Innate Immunity to Mycobacterium tuberculosis Clin Microbiol Rev 2002;15: 294-309.

17. Cattan D. MEFV Mutation Carriers and Diseases Other than Familial Mediterranean Fever: Proved and Non-Proved Associations; Putative Biological Advantage Current Drug Targets - Inflammation\&Allergy 2005; 4: 105-112.

18. Centola M, Wood G, Frucht DM, Galon J, Aringer M, Farrell C. The gene for familial Mediterranean fever, MEFV, is expressed in early leukocyte development and is regulated in response to inflammatory mediators. Blood 2000; 95: 3223-31.

19. Akcan Y, Tuncer S, Unal S, Sökmensuer C, Haznedaroglu CI, Arslan S. Familial Mediterranean fever. No role of Mycobacterium tuberculosis in ten patients. Eur J Med Res 1999; 27: 161-4. 